\title{
Freedom as the Power to Address: Buber's Analysis of the Task of the Educator
}

Mildred Bakan

York University

Some years ago, I was involved in a community school project, indeed, the first such project in the Toronto public school system. It was called Magu, an acronym for Multi-Age Group Unit. The brief submitted to the local Board of Trustees by a group of parents, selftitled "Parents for a Hall-Dennis School," was said to be the very best ever submitted. We anticipated all the questions the newly elected Board of Trustees might raise; we seemed to know where we were going, and despite Administrative recommendation for a delay pending further investigation, the Board of Trustees, responding to the call of the Hall-Dennis report for alternative schools and for community involvement, voted in our favour.

But if we had some sense of what we had in mind, the Administration certainly did not. They issued a call for enrolments in an experimental free school. True enough, the parents were themselves somewhat divided. I alone, of the five who wrote the brief, opposed characterizing the school as "free." I thought the meaning of the word freedom was too confusing to serve as a guide. But we all opposed compulsion of any kind.

The school was closed by the Board of Trustees eight years later. The closure may be taken as an indication of its failure. But many parents and teachers learned a great deal about education from the experience and that knowledge was incorporated in the development of other more successful educational ventures. Three years before Magu was closed, a bitter split broke out among both parents and teachers precisely around the issue of freedom. A large number of parents, including those who had written the brief, and two of the teachers-a husband and wife team-were declared, by the elected community council, to be authoritarian. The two teachers responsible for the primary group (roughly grades 1-6; the school by that time went all the way through high school, an expansion that was in many ways a mistake) were criticized for attempting to mold their young students' minds by involving them in the organized performance of school plays initiated by the students. The issue was not improvisation, of course, but that the teachers presumed to give their students direction. The two teachers withdrew to establish their own private school and their parent clientele enrolled their children. Those who withdrew from the school knew, as the Administration knew, that the school could not long survive, given the interpreta- 
tion of freedom that proved victorious. It was an extreme concept of freedom, as absolute freedom to choose; and it was argued, all students must e given the absolute power of choice.

In the course of this conflict, I wrote and read a brief paper drawing a distinction between authority and authoritarianism, to no avail. True enough, however crucial the distinction, it is difficult to maintain. An authoritarian, I wrote, seeks to influence others by force or the threat of force and correlatively acts to maintain power. An authority, however, acts out of knowledge or something like knowledge without any interest at all in maintaining power.

I later realized that my distinction was Platonic, and when I chanced to read Martin Buber's two essays on education in Between Man and Man out of an interest in dialogue, I recognized that Buber was drawing the same distinction but in our contemporary cultural context. Buber is characteristically interpreted as a philosopher under the influence of Chassidism. I will make the case, largely on the basis of Buber's views on education, that Buber can be understood as a contemporary Platonist.

The two essays, "Education" (Buber, 1973, Chapter III) and "The Education of Character" (Buber, 1973, Chapter IV) elaborate much the same points: freedom is to be interpreted as basically the freedom to respond to the interests and needs of the other in the context of a shared situation; that the essence of education is the education of character, but character cannot be taught, only influenced, in the context of teaching about something-some matter of the world; that the authority of the teacher is an essential component of the relation between teacher and student, the role of the teacher being to bring a selection of the chaotic universe to the student as a worldthe world of the teacher-and to inspire the student's confidence in the teacher by the example of the teacher's own integrity. According to Buber, it is only by winning-or by earning-the student's confidence in him that the teacher can influence the student's character. Character itself is the unity of the person, one's integration as a whole: body and mind, past and future, as unity of life and action, endowing one with the capacity simply to respond. To respond to what? The address of the other. Indeed, freedom itself is to be understood not as freedom of choice, but as freedom to be open to the other.

It is pertinent to note that Buber begins the essay "Education" by taking up Plato's question: Can virtue be taught? Like Plato, Buber's answer is yes and no (Plato, 1978). Values cannot be taught as mathematics or, indeed, any craft is taught. But values are nevertheless learned. And in the learning process the character of the teacher is a critical factor. Buber recognizes that we live in a multicultural world-a world in which we do not share concrete values, and in which we find profound divergence even with respect to belief. In this multi-cultural world, values can only be communicated 
through the person of an educator, who takes it as a task to bring " $\varepsilon$ selection of the effective world"-confirmed through the persona. integrity of the educator-to the student. Thereby, according tc Buber, the teacher calls forth the person in the pupil.

In fact, Plato learned from Socrates, as a person, though the person as a teacher disappears from Plato's thematic concern in favour of what is simply out there. Yet according to Plato, though the cosmos is essentially informed-that is, structured-in terms of form the philosopher-king must himself move out of the darkness of the cave, to apprehend-have a vision of-the Good, which in The Republic is not a form at all but the "light" that allows forms ambiguously both to be and to be beheld (Plato, 1968, VI).

Why is the vision of the Good essential to the education of the philosopher-king? The vision of the Good, I submit, is a vision of the goodness of the being of the forms: that is, of the embodiment of the forms themselves; in effect, a vision of the beauty of the cosmos by virtue of its inherent logos - the ongoing participation of the forms in the ongoing Being of the cosmos through its own self-generation. The vision of the Good is incidentally also a vision of-or insight into, or appreciation of - the good as the appropriate, the fitting, thereby justifying the worldly embodiment of form. For the forms themselves, as the regulating logos of the cosmos, regulate the relation of things and, in effect, establish what is appropriate, fitting, in the cosmos. What is appropriate, fitting, is what is owing to the thing in its situation; in effect, justice in the cosmos itself-that justice which society, as the polis, is to imitate. Only through the vision of the Good can the philosopher-king achieve wisdom allowing judgment regarding what is just and unjust in the affairs of man from the standpoint of the whole rather than from his own self-interest, a wisdom based on a yea-saying to the Being of the cosmos itself (Plato, 1968, VII). The philosopher-king comes back from his vision with an earthly love of the Good, without which he remains an outsider to the polis-and indeed, to the life of the people.

But for Plato, Eros is at work among all things, including the affairs of men, inclining them to the worldly realization of form. That is, for Plato, relations among things are not sharply differentiated in kind from human relations to things. Indeed, we are called to imitate the making of things in the making of society! Most significantly, logos itself is ambiguously both the structure of things and speech. And this position is not unique to Plato. It is typically Greek (Heidegger, 1975; Buber, 1965). ${ }^{1}$ Buber, a modern philosopher, draws a sharp line between the causal relations - the physical relations-between things and the addressive relations of which only humans are capable, both among themselves and to the things of the world, simply by virtue of being the speaking animal. Causal relations define the realm of the necessity. But addressive relations define the realm of freedom. In effect, Buber brings the Greek understanding of freedom, as the freedom from force, up-to-date as the freedom charac- 
teristic of addressive relation, or, as he sometimes also says, the dialogical relation, the relation between I and you.

Like Plato, Buber claims the wisdom of the educator comes not from the application of any principle or criteria, but out of response to what is owing to the situation-its demands. Without a sense of Buber's Platonic roots, Buber becomes only an existentialist, rocked about by the arbitrary demands of his particular situation. However, according to Buber, the educator must respond to the needs and interests of the student-his/her possibilities for development -not out of the preference of (what Buber calls) natural Eros, but out of an Eros transformed by the opening of dialogical relation to the other. The addressive relation between teacher and student is not that of Greek friendship, not any abstract equality, but the quite specific inclusive relation by the teacher towards the student. In an inclusive relation the teacher bears the responsibility of acting out of the disclosure of the student from the side of the student but in the perspective of the teacher's own hierarchy of values, which, however, to be effective, must be the integrated basis of the teacher's own action-deeds. It is relevant to note that the very interpretation by Buber of virtue as integration is itself Platonic. For according to Plato, it is only as an integrated whole-mind, spirit, and appetite - that the soul can act at all: that is, be free both to know and to act out of knowledge (Plato, 1968, IV).

Freedom as the capacity to know is also the capacity to respond rather than be determined simply by drives. And though for Plato nature is not chaos but the problematic achievement of form taking hold of flux, whereas Buber takes nature as chaos, for Buber as for Plato, world, as the analogue of cosmos, is a problematic achievement of form quieting the chaos (Plato, 1956, Sec. 206-208). The opposition of flux and form in Plato is replaced in Buber's thought by the opposition of nature-now called Chaos-and form. But in some of Buber's writings nature itself is taken as ordered by form (Buber, 1970, pp. 57-59). In any case, for Buber the integration of the world in terms of form is the achievement of a person in responsive relation to what is about him-which, indeed, as responded to, is already worldly. The human response to things is first of all a free response to things as themselves addressive, a relation of a social order.

Interhumanly, this relation is shown as speech in which I address another not as a body or a thing, but as a person. In this addressive relation I relate to the other as able to understand and to reply, by actions or words. But I cannot force, or be sure of, another understanding me. That understanding is itself a reciprocal address. Indeed, when I relate interhumanly to another in this way, I am open to an encounter with the other as a unique individual. I do not know where this encounter will lead. In just this sense an encounter can break any preconception that I may have as to the character of this person. 
According to Buber, even when I see another person, I see his/he] body as addressive, as speaking. I see another person's body as ex pressing, as saying, something: as sad, or pained, or angry, or joyful or frightened; as inviting, or threatening; as helpless, or able; etc Indeed, in relating to another in an I-you fashion, I relate to him/heI as embodied and, yet, as a person: here, now, speaking, saying some. thing. To be addressed in this way is to be called upon to understanc in an involved and engaged way, to do as well as to be aware. It is ou1 of the encountered being of others that I am called to act responsibly in this world (Buber, 1970, largely Part I).

Though I can look at trees as mere things, to be causally explainec by their relationship to their environment, I can see them also in an. other way, again as unique, as addressive, as speaking, as relating tc sky and earth, as vital, as living, as coping. This sort of seeing is spoken of poetically and depicted as art. It is the place of symbol anc myth. It is an engagement with others and our world which does nor divorce us from our bodies and yet is not simply an expression of arbitrary impulse. We sometimes encounter the cosmos itself ir these terms. The stars in the night sky speak to us in a certain way if we let them.

We have largely lost this sort of encounter with others and, of course, with things; at least we see it as unimportant in our highly technical society which is primarily concerned with production commodities, and money. But in losing our sense of the world anc others, we lose the sense of the importance, the majesty, and the mystery of the world we live in. We lose the sense of community anc of home. Even the sense of meaning and truth disappears. We be come lost in convention, in "playing the game according to the rules." Knowledge is reduced to a collection of facts and only causa determination is taken as real. According to Buber, we cannot reason our way by proof to the reality and importance of others as per. sons, or to the mystery and majesty of the world. We can, however be open to an encounter with persons and to the world around us.

Indeed, according to Buber, dialogical opening of selves to each other is only a singularly important instance of communal encoun. ter, which can as well occur in our relations with nature and with the universe itself, as the Eternal You (Buber, 1970, largely Part III) When our relationship with persons, with nature, even with things lose the possibility of encounter, we become alienated, susceptible to demoniacal subversion by a will to power, or persona achievement, or profit. God, as Eternal You, holds open the possibil ity of encounter with beings in the world. But human dialogical en counter is itself the concrete source and manifestation of encountes with God as Eternal You.

Yet God can be encountered precisely as addressing us, as calling us from beyond our experience. Every I-You encounter is a call to re sponsible action as well as a disclosure of being. Quite specifically 
God's address calls us to tasks-works-in this world, which embody its potential form and meaning and transform the world into humanity's home. Humanity called to works in this world is called to participate in, to fulfill, God's creation by realizing the form or meaning-spirit—inherent in nature itself.

God, addressing us to act in the world, holds us open for this sort of encounter with the world, with nature, and with other persons. Indeed, God, as absolute address, addresses us to responsibility for the world itself in its being. Addressing us to act in the world, to works, God grounds the direction of our lives, orients our future, and renders our past meaningful. When our lives lose this centered direction, then, to avoid personal chaos, our lives are open to demoniacal subversion. We fall into sin, losing ourselves as well. Our sense of chaos-loss of direction-the analogue of Kierkegaard's dread and Sartre's anxiety - is thus, according to Buber, testimony to our latent potentiality to hear God's call.

How then can persons be united as community? Only through a shared task that is responsive to the world, or rather to the things of the world. But community remains specific, with a specific history in a specific situation.

On the one hand, persons in dialogue with each other share a world and commit themselves to a common task. On the other hand, communities can relate to communities. There is thus a basis for form and organization as specifically relative, though grounded in the Absolute toward which we are turned, the God of all, not so much as the causal origin of the world as the ground of addressive relation. In such communities, there can be respect for knowledge and the orientation to knowledge, as a basis for authority and a touchstone for dialogue about the matter being discussed, without tying the pursuit of knowledge, or acting on the basis of knowledge, to domination. In the special case of education, the teacher, acting out of knowledge, is to remain sensitive to the interests and needs of the students who, guided by the bridge of the teacher's involved selection of the world, can, with confidence in the teacher, rise to the status of an equal.

Buber is strongly critical of the ideal of education as simply the release of creativity empowering the "instinct to create." The simple release of creativity is solitary, a lone making of things. But the task of the educator is to educate for participation in a community with a shared task or tasks, undertaken as a group effort involving an irreducibly addressive relationship among persons. That model of relating must be guided by an educator, the authority whose responsibility it is to guide the student by presenting to the student a selection of the world, and is not simply an expression of spontaneous creativity, a merely natural activity. We can read this as an ideal Plato himself saw inherent in the process of education. 
But, according to Buber, the teacher as guide must be careful not to suppress spontaneity. Spontaneity must be allowed to develop in the context of a world and community. The child is envisioned as developing his/her possibilities through the authoritative and responsible guidance of the teacher. In effect, the educator must be sensitive to the immanent form of character in the student and develop in the student sensitivity to the immanent form of others and of the things of the world through his words, deeds, and more generally his personal example.

Instead of criteria, Buber substitutes sensitivity to immanent form. Between the lines we read that even this immanent form is not a solitary matter but an emergent in the context of ongoing dialogue and concerted action with others (Buber, 1965). Instead of absolute knowledge, Buber substitutes the ongoing process of dialogical sharing of the world.

In the experimental community school in which I was involved, people wearied of the continued discussion that marked its early, heady stage. Impatient with the uncertainty of consensus, they sought the participation of election to office and the authoritarian power of a community council which lost dialogical relation to what was going on in the school. The school, itself formed in criticism of the arbitrary authoritarianism of teacher and principal in the conventional school, did not overcome the isolation that characterizes authoritarian relationships. Having removed the power of the authoritarian, the students remained isolated from the teacher, abandoned to their individual power of choice. In fact, the students did group together in their insecurity, in cliques, even gangs, substituting their own power relation for the true authority of a teacher (Schmuck \& Schmuck, 1974, pp. 5, 16-17, 178, 182; generally Chapter 1). ${ }^{2}$

\section{Notes}

1. Both Heidegger and Buber trace this understanding of logos to Heraclitus.

2. This is not an atypical occurrence in such situations. It is relevant to note that the authors take Buber's thought as central to their "thinking about humanized schools."

\section{References}

Buber, M. (1965). What is common to all. The knowledge of man. New York: Harper \& Row.

Buber, M. (1970). In W. Kaufman (Trans.), I and Thou. New York: Charles Scribner's Sons.

Buber, M. (1973). In R. Smith (Trans.), Between man and man. London: Collins.

Heidegger, M. (1975). Logos (Heraclitus, Fragment B50). Early Greek thinking. New York: Harper \& Row. 
Plato. (1956). In B. Jowett (Trans.), Symposium. Sec 206-212. Library of Liberal Arts, Indianapolis: Bobbs Merrill.

Plato. (1968). In A. Bloom (Trans.), The Republic of Plato. IV, Sec. $443 \mathrm{~d}$, e, 444 a, 437-442. New York: Basic Books.

Plato. (1968). In A. Bloom (Trans.), The Republic of Plato. VI, Sec. 508, 509. New York: Basic Books.

Plato. (1968). In A. Bloom (Trans.), The Republic of Plato. VII, Sec. 517 b, c. New York: Basic Books.

Plato. (1978). In B. Jowett (Trans.), Meno. Library of Liberal Arts, Indianapolis: Bobbs Merrill.

Schmuck, R. A., \& Schmuck, P. A. (1974). A humanistic psychology of education. Palo Alto, California: National Press. 